\title{
BIBLIOTECÁRIOS, DIREITOS AUTORAIS E ACESSO ABERTO: estudo sobre as influências na prática profissional em SC
}

\author{
MARCIA SILVEIRA KROEFF* \\ MIRIAM DE CASSIA DO CARMO MASCARENHAS MATTOS* \\ LILIANA FÁTIMA**
}

\begin{abstract}
RESUMO
Esta pesquisa averiguou o conhecimento dos bibliotecários de Santa Catarina acerca da Lei Brasileira de Direitos Autorais (LDA) e seu grau de adesão ao Movimento de Acesso Aberto à informação científica. A revisão de literatura questiona os direitos autorais e apresenta o "Dossiê Copy/South", bem como a legislação brasileira de direitos autorais. O estudo exploratório-descritivo foi realizado em 2017, com 53 bibliotecários. Os resultados indicam que estes têm conhecimento da proteção aos direitos, mas desconhecem seu tempo de vigência. Em relação à reprografia, relatam dificuldades com as imposições legais. A orientação ao usuário na citação de autoria e referências bibliográficas é adequada. Já as bases de dados e seus contratos não estão claras aos bibliotecários. Estes demonstram adesão ao Movimento de Acesso Aberto e consideram mais importante o acesso livre à informação científica do que a prevalência dos direitos autorais, priorizando a satisfação das necessidades informacionais de seus usuários.
\end{abstract}

PALAVRAS-CHAVE: Direitos autorais. Lei 9.610. Movimento de Acesso Aberto. Open Access. Bibliotecários.

\begin{abstract}
This research investigated the knowledge of librarians in Santa Catarina about the Brazilian Copyright Law (LDA) and its degree of adherence to the Open Access Movement to scientific information. The literature review questions copyright and presents the "Copy/South Dossier" as well as Brazilian copyright law. The exploratory-descriptive study was carried out in 2017, with 53
\end{abstract}

\footnotetext{
* Professora do Departamento de Biblioteconomia do Centro de Ciências Humanas e da Educação da Universidade do Estado de Santa Catarina.

** Professora da Universidade de Caxias do Sul (UCS).

*** Professora do Departamento de Biblioteconomia do Centro de Ciências Humanas e da Educação da Universidade do Estado de Santa Catarina (UDESC).
} 
librarians. The results indicate that they are aware of the protection of the rights, but are unaware of its validity. In relation to reprography, they report difficulties with legal impositions. The orientation to the user in the citation of authorship and bibliographical references is adequate. The databases and their contracts are not clear to librarians. These demonstrate adhesion to the Open Access Movement and consider that free access to scientific information is more important than the prevalence of copyright, prioritizing the satisfaction of the informational needs of its users.

KEYWORDS: Copyright. Law 9.610. Open Access Movement. Open Access. Librarians.

\section{INTRODUÇÃO}

Se por um lado a evolução tecnológica ampliou a possibilidade de acesso e compartilhamento da informação, por outro, leis como as de direitos autorais e as bases de acesso restrito privatizam tal possibilidade. De quebra, colocam em xeque a própria função social do bibliotecário e, de certa forma, reduzem a informação e a cultura à condição de mercadoria.

Num passado recente, as editoras, assim como as gravadoras, tinham a função de fazer o conhecimento chegar ao público. Essa mediação era necessária, pois envolvia um complexo sistema de produção, distribuição, logística, planejamento, assim como custos de estocagem, além das parcelas de participação dos varejistas e distribuidores. Hoje as tecnologias de informação e comunicação quebraram essa cadeia que havia entre 0 produtor/autor e o leitor/consumidor.

Tal situação, dentre outras, vem despertando um debate internacional sobre os direitos de propriedade intelectual, o acesso aberto à informação, os processos decisórios sobre acordos comerciais multilaterais e bilaterais, além de ajustes de legislações internas dos países. Vem, também, propiciando a emergência de movimentos sociais contestatórios a esta "nova ordem".

Debates que relacionam "acesso aberto" e "direitos autorais" são contemporâneos e ambos os temas envolvem e influenciam diretamente as práticas dos profissionais da informação, sobretudo dos bibliotecários. Neste sentido, é perceptível a necessidade de aprofundamento no assunto, principalmente no que se refere aos impactos e consequências das leis e acordos firmados para as Instituições, seus profissionais e usuários. Nesta direção, a pergunta central que norteou a pesquisa foi: Qual o nível de conhecimento que os bibliotecários de Santa Catarina possuem acerca da Lei 
Brasileira de Direitos Autorais e do Movimento de Acesso Aberto à informação científica e como agem em seu cotidiano profissional?

Como objetivo geral do estudo pretendeu-se averiguar o nível de conhecimento que os bibliotecários de Santa Catarina possuem acerca da Lei Brasileira de Direitos Autorais e o grau de adesão ao Movimento de Acesso Aberto à informação científica. Para tanto, elaborou-se alguns objetivos específicos elencados a seguir: a) levantar e analisar os regulamentos e normativas acerca dos diretos autorais no Brasil; b) verificar o nível de conhecimento que os bibliotecários de Santa Catarina possuem acerca da Lei Brasileira de Direitos Autorais; c) conhecer a realidade dos bibliotecários no que se refere ao cumprimento da Lei Brasileira de Direitos Autorais; d) investigar o grau de adesão dos bibliotecários ao Movimento de Acesso Aberto, enquanto mediadores da informação; e) verificar a frequência de busca aos documentos científicos disponibilizados por acesso aberto.

\section{DIREITOS AUTORAIS, DIREITOS DOS AUTORES?}

A partir de uma análise do "El Dossier Copia/Sur: problemas económicos, políticos e ideológicos del copyright (derecho de autor) en el Sur global"', busca-se refletir sobre algumas das questões abordadas, principalmente aquelas referentes ao capítulo intitulado "De cómo el copyright impide a los bibliotecarios proporcionar servicios a sus usuarios". Nossa atenção volta-se à pergunta: "Como - cientista da informação brasileiro deveria responder aos problemas e conflitos apresentados pelas leis de direito autoral?". Nesta perspectiva, discutem-se alguns aspectos de possíveis confrontos legais e morais associados às tecnologias e ao acesso social à informação.

O Dossiê Copy/South (Sul Global) constitui-se como um documento denso, crítico, reflexivo, e revela as controvérsias que rodeiam as leis de Direitos Autorais em diversos países. O documento denuncia os benefícios dos países desenvolvidos do Norte em relação aos países em desenvolvimento do Sul, visto que os primeiros, por meio das multinacionais, já possuem uma porcentagem esmagadora da propriedade intelectual mundial. Neste sentido, o dossiê destaca as crescentes imposições e pressões institucionais internacionais na perspectiva de cerceamento do Copyright.

\footnotetext{
1 Disponível em inglês em www.copysouth.org e em espanhol em http://eprints.rclis.org/11451/.
} 
Publicado em 2006 na língua inglesa, pelo grupo de pesquisa "Copy South" (GPCS), que é formado por diferentes universidades no mundo, e conta com a participação de estudantes ativistas da reforma do direito autoral, ${ }^{2}$ o documento original foi editado por Alan Story, Colin Darch e Debora Halbert. Em 2007 foi traduzido e publicado em espanhol, apoiado pelo governo da Venezuela ${ }^{3}$. e em 2009 e 2010 foi apresentado e discutido no Brasil ${ }^{4}$.

Ao fazer uma avaliação crítica ao Copyright e seu impacto nos países do Sul Global, o Dossiê apresenta exemplos dos resultados sociais negativos nestes países, afirmando a necessidade da ampliação do livre acesso ao conhecimento, à proteção das culturas locais e à diversidade cultural. $\mathrm{O}$ documento aponta barreiras impostas à sociedade escamoteadas nas ideologias que sustentam as políticas culturais hegemônicas, que impedem o amplo acesso à cultura, à informação e ao conhecimento. (STORY; HALBERT; DARCH, 2006).

Direitos de acesso ao conhecimento, à informação e à cultura são elementos essenciais para o desenvolvimento da sociedade. Entretanto, estes direitos muitas vezes entram em conflito com as leis de direitos autorais, devido às restrições impostas pelas mesmas, que se justificam por um suposto direito do autor. Estes direitos autorais visam estimular uma determinada prática social que é o incremento da atividade criativa do homem para o desenvolvimento econômico, cultural e tecnológico da sociedade. Porém, segundo Carboni (2006, p. 229),

2 Escrito e publicado pelo Grupo de Investigacion Copia/Sur composto por Alan Story (Reino Unido), Colin Darch (África do Sul), Debora Halbert (EUA), Adam Mannan (Reino Unido), Akalemwa Ngenda (Zâmbia), Beatriz Busaniche (Argentina), Denise Nicholson (África do Sul), Federico Heinz (Argentina), Jennifer de Beer (África do Sul), Norah Mugambi (Quênia), Joost Smiers (Holanda), Jose Antonio Torres Reyes (México), Juan Publio Triana Cordovi (Cuba), Lawrence Liang (Índia), Maud Stephan (Líbano), Roberto Verzola (Filipinas), Ronaldo Lemos (Brasil), Shishir Kumar Jha (Índia), Zapopan Martin Muela-Meza (México), Carlos Affonso Pereira de Souza (Brasil), Papa Toumane Ndiaye (Senegal), Majid Yar (Reino Unido), e Teresa Hackett (Irlanda). Editores: Alan Story (Reino Unido), Colin Darch (África do Sul), Debora Halbert (EUA).

${ }^{3}$ Através do Serviço Autônomo de Propriedade Intelectual, no âmbito do Ministério do organismo Poder Popular para as Indústrias Leves e Comércio da República Bolivariana da Venezuela, MPPILCO - SAPI.

${ }^{4}$ Alan Story veio ao Brasil em 2009, ministrando, juntamente com a professora Nanci Odone, a disciplina "Tópicos Especiais - Infopolítica: Tópicos Contemporâneos sobre Propriedade Intelectual \& Direito Autoral e sua Aplicação no Contexto das Tecnologias Eletrônicas de Informação e Comunicação", na Pós-graduação em Ciência da Informação da UNESP. Foi neste contexto que passamos a conhecer o documento e analisá-lo. Em 2010, no Rio de Janeiro, Story também participou da $3^{\text {a }}$ Conferência Internacional sobre Direito Autoral, realizada com o apoio do IBICT. 
As transformações sociais advindas, principalmente, das novas tecnologias, levaram a uma mudança de função do direito de autor: de mecanismo de estímulo à produção intelectual, ele passou a representar uma poderosa ferramenta da indústria dos bens intelectuais para a apropriação da informação enquanto mercadoria, ocasionando uma redução da esfera da liberdade de expressão e se transformando em um obstáculo a formas mais dinâmicas de criação e circulação de obras intelectuais.

Neste sentido, de acordo com Carboni (2006), a função social do direito de autor, que deveria promover o desenvolvimento econômico, cultural e tecnológico mediante a concessão de um direito exclusivo para a utilização e exploração de determinadas obras intelectuais por certo prazo, passa a ser centralizada e direcionada para fins de beneficiar financeiramente um grupo muito seleto de pessoas que, sem nada criar, se utiliza de estruturas proporcionadas pelo capital para vender e lucrar sobre produções científicas e culturais. Muitas vezes inclusive sobre obras financiadas com recursos públicos.

Hoje o interesse da indústria dos bens intelectuais move todo um processo de alargamento do objeto de proteção do direito de autor e de prolongamento do seu prazo de proteção. É por essa razão que o direito de autor mascara o fato de funcionar como uma poderosa ferramenta da indústria do entretenimento e da informação e não do sujeito-autor, que se vê na condição de ter que abrir mão de seus direitos em prol dessa indústria, para que a mesma possa auferir lucro com a comercialização da sua obra.

Lemos (2005) observa que, durante o século $X X$, a propriedade intelectual propiciava razoavelmente o equilíbrio entre os direitos autorais e os interesses da sociedade. A partir da década de 1990, no entanto, os direitos decorrentes da criação passaram a ser encarados como "propriedade" absoluta. A Lei se tornou o principal instrumento de mudança, ampliando substancialmente o poder dos detentores de propriedade.

Existem diversos acordos internacionais quanto à proteção de direitos autorais e direitos conexos, como: a Convenção de Berna para Proteção de Obras Literárias e Artísticas (1886); a Convenção de Roma para Proteção de Intérpretes e Executantes, Produtores de Fonogramas e Organizações de Radiodifusão (1961); o Tratado de Direito Autoral da WIPO (Organização Mundial de Propriedade Intelectual - 1996) e o Tratado de Execuções, Interpretações e Fonogramas da WIPO (1996). O Acordo da Organização Mundial de 
Comércio (WTO) sobre Aspectos dos Direitos de Propriedade Intelectual Relativos ao Comércio (TRIPS), de 1994, é o primeiro acordo multilateral de propriedade intelectual relativo ao comércio (ABARZA; KATZ, 2002, apud LIMA, 2006, p. 7).

Os referidos instrumentos internacionais e a legislação dos países indicam uma preocupação crescente das nações em proteger os aspectos patrimoniais decorrentes da exploração comercial de obras intelectuais. Principalmente os grandes países exportadores destes bens passaram a desejar uma proteção mais severa aos seus produtos. Esse movimento explicita, nas negociações internacionais, uma tendência que visa atrelar os "direitos de propriedade intelectual" apenas com o aspecto econômico.

Iniciativas recentes defendem novos instrumentos para excluir os bens culturais e serviços das regras do comércio internacional. Discutese a inclusão de itens que promovam a expressão e a diversidade cultural. Entre essas iniciativas pode-se citar a Declaração Universal sobre a Diversidade Cultural, da Organização das Nações Unidas para a Educação, a Ciência e a Cultura (Unesco), de 2001, que afirma:

Frente às mudanças econômicas e tecnológicas atuais, que abrem vastas perspectivas para a criação e a inovação, deve-se prestar uma particular atenção à diversidade da oferta criativa, ao justo reconhecimento dos direitos dos autores e artistas, assim como ao caráter específico dos bens e serviços culturais que, na medida em que são portadores de identidade, de valores e sentido, não devem ser considerados como mercadorias ou bens de consumo como os demais. (ORGANIZAÇÃO DAS NAÇÕES UNIDAS PARA A EDUCAÇÃO, A CIÊNCIA E A CULTURA, 2001).

São vários os eventos promovidos pelas mais diversas instituições com objetivo de mostrar que a propriedade intelectual pode ser trabalhada de forma interdisciplinar e intersetorial, num esforço de busca coletiva e solidária de enfrentamento dos modelos que regulam a produção e a apropriação do conhecimento. Muitos eventos contribuem no debate sobre as implicações dos direitos autorais para o acesso ao conhecimento, à saúde, à segurança alimentar, especialmente por tais demandas constituírem carências notadamente dos países tecnologicamente dependentes.

Argumenta-se que a proteção excessiva da criação gera muitos entraves ao surgimento de novas criações, inclusive prejudicando a diversidade cultural.

Ainda sob o âmbito internacional, Rozados e Reis (2014) destacam o surgimento de novas formas de proteção, por meio de 
licenças de uso como o Creative Commons, Copyleft e Digital Right Management, que serão abordadas com detalhes mais adiante neste trabalho.

\section{LEGISLAÇÃO BRASILEIRA}

"No Brasil, em 11 de agosto de 1827, surgiu a primeira lei sobre o direito do autor que, além de criar os cursos jurídicos nas cidades de Olinda e São Paulo, determinou privilégio exclusivo pelo período de 10 anos à produção acadêmica dos professores sob determinadas condições relacionadas na própria Lei." (SOUZA et al., 2012, p. 59).

Vigora atualmente no Brasil a Lei $n^{\circ} 9.610$, de 19 de fevereiro de 1998, conhecida como Lei de Direitos Autorais (LDA), que foi sancionada pela Presidência da República com o objetivo de alterar, atualizar e consolidar a legislação sobre direitos autorais, ou seja, regular os direitos do autor e os que lhe são conexos ${ }^{5}$.

$O$ artigo $7^{\circ}$ da referida Lei define as obras intelectuais protegidas, que são aquelas advindas da criação, pensamento e expressão, em qualquer meio, já conhecidas ou que venham a ser inventadas futuramente, que são:

I - os textos de obras literárias, artísticas ou científica

II - as conferências, alocuções, sermões e outras obras da mesma natureza;

III - as obras dramáticas e dramático-musicais

IV - as obras coreográficas e pantomímicas, cuja execução cênica se fixe por escrito ou por outra qualquer forma;

$\mathrm{V}$ - as composições musicais, tenham ou não letras;

VI - as obras audiovisuais, sonorizadas ou não, inclusive as cinematográficas;

VII - as obras fotográficas e as produzidas por qualquer processo análogo ao da fotografia;

VIII - as obras de desenho, pintura, gravura, escultura, litografia e arte cinética;

IX - as ilustrações, cartas geográficas e outras obras da mesma natureza;

$\mathrm{X}$ - os projetos, esboços e obras plásticas concernentes à geografia, engenharia, topografia, arquitetura, paisagismo, cenografia e ciência;

5 Referem-se à proteção para artistas intérpretes ou executantes, produtores fonográficos e empresas de radiodifusão, em decorrência de interpretação, execução, gravação ou veiculação das suas interpretações e execuções. (UNIVERSIDADE TECNOLÓGICA FEDERAL DO PARANÁ, 2016). 
$\mathrm{XI}$ - as adaptações, traduções e outras transformações de obras originais, apresentadas como criação intelectual nova;

XII - os programas de computador;

XIII - as coletâneas ou compilações, antologias, enciclopédias, dicionários, bases de dados e outras obras, que, por sua seleção, organização ou disposição de seu conteúdo, constituam uma criação intelectual.

Os direitos morais do autor, isto é, o direito à paternidade ou denominação da obra, estão previstos nos artigos $24^{\circ}$ a $27^{\circ}$ da LDA, assim dispostos:

Art. 24. São direitos morais do autor:

I - o de reivindicar, a qualquer tempo, a autoria da obra;

II - o de ter seu nome, pseudônimo ou sinal convencional indicado ou anunciado, como sendo o do autor, na utilização de sua obra;

III - o de conservar a obra inédita;

IV - o de assegurar a integridade da obra, opondo-se a quaisquer modificações ou à prática de atos que, de qualquer forma, possam prejudicá-la ou atingi-lo, como autor, em sua reputação ou honra;

$V$ - o de modificar a obra, antes ou depois de utilizada;

$\mathrm{VI}$ - o de retirar de circulação a obra ou de suspender qualquer forma de utilização já autorizada, quando a circulação ou utilização implicarem afronta à sua reputação e imagem;

VII - o de ter acesso a exemplar único e raro da obra, quando se encontre legitimamente em poder de outrem, para o fim de, por meio de processo fotográfico ou assemelhado, ou audiovisual, preservar sua memória, de forma que cause o menor inconveniente possível a seu detentor, que, em todo caso, será indenizado de qualquer dano ou prejuízo que lhe seja causado.

Art. 25. Cabe exclusivamente ao diretor o exercício dos direitos morais sobre a obra audiovisual.

Art. 26. O autor poderá repudiar a autoria de projeto arquitetônico alterado sem o seu consentimento durante a execução ou após a conclusão da construção.

Parágrafo único. O proprietário da construção responde pelos danos que causar ao autor sempre que, após o repúdio, der como sendo daquele a autoria do projeto repudiado.

Art. 27. Os direitos morais do autor são inalienáveis e irrenunciáveis. (BRASIL, 1998).

Os direitos de usar, usufruir, explorar - inclusive economicamente - as produções literárias científicas ou artísticas, são definidos como direitos patrimoniais e sua duração e constam nos artigos $28^{\circ}$ a $45^{\circ}$ da LDA. E os direitos conexos e sua duração são contemplados no Título V, artigos $89^{\circ}$ a $100^{\circ}$ da Lei. 
É importante salientar que as sanções de ordem civil são estabelecidas na LDA (do Art. 101 até o Art. 110), sendo que se aplicam sem prejuízo das penalidades cabíveis. As violações dos direitos autorais e suas respectivas penalidades estão previstas no artigo 184 do Código Penal Brasileiro.

A LDA teve alguns dispositivos alterados, revogados e acrescentados pela Lei $n^{\circ} 12.853$, de 14 de agosto de 2013, principalmente no Título VI - Das associações de titulares de direitos de autor e dos que lhes são conexos.

Conforme afirmam Paranaguá e Branco (2009), citados por Souza et. al (2012), a LDA brasileira "é tida como uma das mais rígidas do mundo, impondo sólidas barreiras ao acesso à diversos tipos de informações científico-culturais".

\section{CONSTITUIÇÃO FEDERAL: O DIREITO DO AUTOR E O DIREITO DO CIDADÃO AO ACESSO À INFORMAÇÃO}

A Constituição da República Federativa do Brasil foi promulgada em 05 de outubro de 1988 e trata, em alguns artigos e incisos, do direito do autor, da liberdade de expressão e ao acesso à informação. Os direitos do autor e de propriedade intelectual estão inseridos no TíTULO II - Dos Direitos e Garantias Fundamentais, CAPÍTULO I - Dos Direitos e Deveres Individuais e Coletivos, Art. $5^{\circ}$ da Constituição Federal, que estabelece:

Todos são iguais perante a lei, sem distinção de qualquer natureza, garantindo-se aos brasileiros e aos estrangeiros residentes no País a inviolabilidade do direito à vida, à liberdade, à igualdade, à segurança e à propriedade, nos termos seguintes:

[...] XXVII - aos autores pertence o direito exclusivo de utilização, publicação ou reprodução de suas obras, transmissível aos herdeiros pelo tempo que a lei fixar;

XXVIII - são assegurados, nos termos da lei:

a) a proteção às participações individuais em obras coletivas e à reprodução da imagem e voz humanas, inclusive nas atividades desportivas;

b) o direito de fiscalização do aproveitamento econômico das obras que criarem ou de que participarem aos criadores, aos intérpretes e às respectivas representações sindicais e associativas. (BRASIL, 1988).

Carboni (2005) observa que os incisos acima tratam apenas dos direitos patrimoniais do autor, pois referem-se ao direito de uso e aos herdeiros, e que a Constituição não contempla o direito moral do autor em nenhum dos seus artigos. 
Ainda no artigo $5^{\circ}$ da Constituição Federal, temos o inciso IX, que define a liberdade de expressão: "IX - é livre a expressão da atividade intelectual, artística, científica e de comunicação, independentemente de censura ou licença".

Conclui-se que as restrições quanto ao uso de produções intelectuais não contemplam a liberdade de expressão. Segundo Carboni (2005, p. 22),

A medida que aumenta o grau de proteção do direito do autor (tanto com relação ao seu escopo, quanto ao prazo de proteção), aumenta o nível de interferência e de restrição à liberdade de expressão, $[. .$.$] a menos que haja uma expressa anuência do seu$ criador, ou em circunstâncias expressamente admitidas por lei, em caráter de exceção.

O livre acesso à informação também é garantido pela Constituição Federal, TíTULO II - Dos Direitos e Garantias Fundamentais, CAPÍTULO I - Dos Direitos e Deveres Individuais e Coletivos, Art. $5^{\circ}$. "Todos são iguais perante a lei, sem distinção de qualquer natureza, garantindo-se aos brasileiros e aos estrangeiros residentes no País a inviolabilidade do direito à vida, à liberdade, à igualdade, à segurança e à propriedade, nos termos seguintes:

...

XIV - é assegurado a todos o acesso à informação e resguardado o sigilo da fonte, quando necessário ao exercício profissional". (BRASIL, 1988).

De acordo com Carboni (2005), o direito de acesso à informação, em tempos de internet, é o que mais conflita com os direitos autorais, em razão da facilidade de obter livremente as informações e utilizá-las. 


\section{ACESSO ABERTO: luta entre Davi e Golias ${ }^{6}$}

Acesso livre não é um sonho idealista, mas um

objetivo que procura harmonizar as necessidades de um sistema de comunicação economicamente sustentável com as necessidades intelectuais. Trata-se de um modelo que representa um sistema de distribuição de inteligências, é uma forma de dizer como é possível fazer melhor uso de todas as mentes do mundo. (GUÉDON, 2004a, apud WEITZEL, 2005).

Em tempos de internet e de constantes novidades tecnológicas, vivemos profundas transformações nas relações sociais. Surge a sociedade em rede, com destaque para a comunicação e produção de conhecimento. Barreto (2012, p. 15) entende que "a sociedade em rede permite partilhar o saber para se ter uma sociedade do conhecimento compartilhada, porque cada indivíduo entra no universo tecnológico das redes interligadas trazendo sua cultura, suas memórias cognitivas e sua odisseia particular".

Neste contexto, o conhecimento socialmente produzido tem diferentes dinâmicas, dentre elas a científica, aqui entendida como prática que concretiza-se, segundo Stoleroff e Patrício (1995, p. 54), "em resultados, ou seja, patentes, que registram um processo, um produto ou um artefato, textos que servem para divulgar uma descoberta e/ou uma inovação, ou os serviços que respondem a encomendas". Dessa forma, a produção científica é inegavelmente fruto da pesquisa científica. Assim sendo, o conhecimento científico é produto da ciência, dado a conhecer por meio da produção científica.

Lourenço (1997, p. 25) define produção científica como "toda produção documental, independente do suporte desta - papel ou meio magnético - sobre um determinado assunto de interesse de uma comunidade científica específica, que contribua para o desenvolvimento da ciência e para a abertura de novos horizontes de pesquisa".

\footnotetext{
${ }^{6}[\ldots]$ Mas, todos os israelitas estavam com medo de Golias, porque era muito grande. Tinha uns 3 metros de altura, e tinha outro soldado para carregar-lhe o escudo. Alguns soldados foram contar ao Rei Saul que Davi queria lutar contra Golias. Mas, Saul disse a Davi: 'Não pode lutar contra este filisteu. Você é apenas rapaz, e ele foi toda a vida soldado. [...] Então, Davi correu para Golias. Tirou uma pedra da bolsa, colocou-a na funda e atirou-a com toda a força. A pedra atingiu Golias bem na cabeça, e ele caiu morto! - Luta entre Davi e Golias. Histórias bíblicas.
} 
No mundo capitalista, a produção e o conhecimento científico transformam-se em mercadorias, gerando grandes lucros para empresas que monopolizam seu acesso. Neste sentido, a referência à luta entre Davi e Golias é uma analogia à luta daqueles que defendem o acesso aberto da produção científica (Davi), reforçando a possibilidade de construírem-se alternativas que alterem o status quo do conhecimento científico, contra os que entendem e usam a produção científica como mercadoria lucrativa (Gigante Golias).

\section{SEMPRE FOI ASSIM? SEMPRE SERÁ ASSIM?}

Segundo Barreto (2012), o livre fluxo da informação, a adequada distribuição (equitativa) do conhecimento produzido pela humanidade tem sido sonho de diversos homens em diversas épocas, sendo as organizações sociais aquelas que primeiro se ocuparam com a inclusão pelo conhecimento.

Criada em 1603, a Academia de Lince (Accademia de Lincei) foi a pioneira. "A meta das primeiras academias era a de possibilitar a qualquer pessoa do povo saber o que era ciência e como eram feitas as descobertas científicas [...] em suas reuniões o que se praticava geralmente era a realização de experimentos para que os leigos as vissem". (BARRETO, 2012, p. 17). Formava-se, assim, a consciência da importância da troca de informações entre os pesquisadores que, de forma oral ou por meio de correspondências, relatavam suas pesquisas a outros estudiosos e à sociedade. As experiências relatadas podiam ser testadas e aperfeiçoadas por outros interessados, realimentando o processo de pesquisa e gerando novos conhecimentos científicos.

Com a aplicação do Método Científico, consolidado no século XVII, ampliou-se a comunicação e registro da informação científica e em consequência surgem os primeiros veículos de informação científica: os periódicos. As revistas científicas, em seu sentido moderno, nasceram na segunda metade do século XVII, em Londres/Inglaterra (Philosophical Transactions of the Royal Society) e em Paris/França (Journal des Sçavans). (MEADOWS, 1999). Juntamente com o surgimento dos periódicos, a criação da Encyclopédie, editada por Jean Le Rond d'Alembert e Denis Diderot, que contou com a contribuição de Voltaire, Rousseau e Montesquieu. Publicada na França, no século XVIII - volumes finais em 1772, foi vista como a destruição das superstições para o acesso ao conhecimento humano. (BARRETO, 2012, p. 18). 
O surgimento dos periódicos deu-se porque os livros já não atendiam mais à velocidade de troca de informações exigida no campo das ciências, além da necessidade de comunicação, de modo mais eficiente para uma clientela crescente e interessada em novas realizações. Fez-se necessário, assim, um veículo de informação mais rápido e atualizado.

Corazza e Duarte (1984) enfatizam o importante papel desempenhado pelas revistas científicas no contexto da divulgação científica e afirmam que a publicação é produto indispensável da atividade científica, sendo através dela que o pesquisador comunica o resultado de seu trabalho.

Com o passar dos séculos, por conta da evolução tecnológica, a produção e a divulgação científica sofreram modificações, o registro das informações deixou de ser meramente impresso para existir em meio digital, além de ter seu acesso ampliado em função da internet.

No entanto, ressalta-se que a enciclopédia e as revistas (sécs. XVII e XVIII) foram as primeiras redes do saber acumulado (embora com conexões fixas) e denotam claramente que a preocupação com o acesso ao conhecimento livre e para todos não surgiu com a internet.

No meio científico, o aparecimento de revistas eletrônicas impulsionou o acesso à informação, haja visto que antes as revistas passavam por um longo período até serem impressas e chegarem às mãos dos pesquisadores. Meadows (1999) afirma que a quantidade de informação em circulação se ampliou, bem como sua forma de apresentação.

A crise dos periódicos, no final da década de 1990, ocasionada pelo crescente aumento dos valores das assinaturas, que impossibilitava a manutenção das coleções de periódicos, impulsionou o surgimento do Movimento de Acesso Livre. (PRADO, 2014).

Para Guedon (2001), a propriedade intelectual surgiu com intuito de proteger o comércio dos textos impressos contra a imitação e a pirataria, que se equiparava à propriedade exclusiva e perpétua concedida para a terra. Segundo o autor, o direito autoral surgiu inicialmente como uma recompensa e proteção temporária concedida pela República ao cidadão, contrariando princípios norteadores do conhecimento científico, como a democratização do saber. Ao relacionar a disseminação do conhecimento científico com os conceitos iniciais de propriedade intelectual, esse processo foi descaracterizado, comprometendo a democratização do saber. Com o avanço das tecnologias digitais, novos debates surgiram e novas 
sanções do comércio de revistas científicas passaram a restringir seu acesso.

Ainda segundo Guedon (2001), nos últimos 50 anos os editores conseguiram transformar revistas acadêmicas tradicionais em um empreendimento editorial promissor, "um grande negócio com altas taxas de lucros". O autor apresenta algumas questões que nos fazem refletir: Qual é a base real por trás dessa capacidade surpreendente? Para benefício de quem? Quais as fases de transição que podemos esperar? Qual é a fonte de seu poder? Como pode ser subvertido? (GUEDON, 2001, p. 45).

Para Sayão (2010), também há muitas perguntas que ainda devem ser respondidas. Isto porque a definição de um modelo é ameaçada por incertezas que tornam o desenvolvimento de estratégias de arquivamento extremamente difíceis. Algumas questões que estão em pauta são sob a perspectiva da biblioteca, entre elas:

Quais são os direitos de acesso permanente ao material já pago, principalmente quando a biblioteca suspende a assinatura do periódico? $\mathrm{O}$ que acontece quando o editor retira um trabalho eletrônico do acesso on-line, ou se afasta do negócio, ou torna, por outro motivo qualquer, o acesso inviável? Quem vai assegurar que os arquivos vão manter a sua usabilidade? E quem vai pagar por isso? (JANSEN, 2006, apud SAYÃO, 2010, p. 76).

Questionamentos como os de Guedon e Sayão impulsionam o debate sobre o Movimento de Acesso Aberto (Open Access, em inglês). $O$ encarecimento das assinaturas dos periódicos e a dificuldade das bibliotecas em adquiri-las reforçam o movimento.

Ainda há outros questionamentos. Abadal et al. (2010), apud Rodrigues e Oliveira (2012), explicam que na América e em alguns países do Sul da Europa as motivações do apoio ao acesso aberto são similares (diferindo em parte do Canadá e Estados Unidos), pois ganham especificidades como: publicações em outras línguas que não o inglês, a falta de periódicos, por não terem indústria editorial forte e tendem a investir menor porcentagem do PIB em pesquisas.

Defensores do acesso livre de diversos países, principalmente aqueles em desenvolvimento, passam a questionar o formato e o lucro das grandes empresas, indicar e promover modelos alternativos para comunicação científica, como repositórios digitais, fazendo frente às dificuldades mencionadas. Esses modelos alternativos desencadearam a mudança do sistema tradicional de comunicação científica. $O$ debate 
ganhou força também por parte de alguns governos com iniciativas e incentivos a fim de intervir em favor do acesso aberto e da publicação paralela de artigos publicados em periódicos baseados em assinatura.

Kuramoto (2006, p. 93) aponta os manifestos e declarações internacionais que apoiam essa inciativa, como o de Budapeste ${ }^{7}$, de Bethesda ${ }^{8}$ e o de Berlim ${ }^{9}$.

Mais recentemente, em 2014, a Declaração de Haia ${ }^{10}$ também manifesta a preocupação de validar e disponibilizar a informação científica produzida de forma ampla, eficiente e rápida para a sociedade.

Kuramoto (2006) menciona também o manifesto do Instituto Brasileiro de Informação em Ciência e Tecnologia (IBICT), lançado em 13 de setembro de 2005, nascido em decorrência da dificuldade de acesso às publicações científicas que até aquele momento só poderiam ser obtidas por meio de assinaturas de periódicos, e das novas tecnologias, como os repositórios institucionais e softwares livres, que possibilitaram o acesso e o fluxo das informações.

Kuramoto (2006, p. 93) explica que

O IBICT foi criado com o propósito de registrar e disseminar a produção científica brasileira. Com o surgimento das tecnologias da informação e da comunicação, combinando com o movimento do acesso livre à informação, verifica-se a existência de um cenário amplamente favorável ao Instituto para o cumprimento de sua missão inicial. Assim, [...] inicia o desenho de uma política nacional de acesso livre à informação científica, tendo esse manifesto como guia orientador para a definição dessa política.

\footnotetext{
7 Budapest Open Access Inititative (BOAI) - reunião organizada pelo Open Society Institute (OSI), em dezembro de 2001, onde foi feita a Declaração de Budapeste sobre acesso aberto e livre. (PIMENTA et. al. , 2015, p. 135).

${ }^{8}$ A Declaração de Bethesda foi realizada em 11 de abril de 2003, na sede do Howard Hughes Medical Institute, em Chevy Chase, Maryland, Estados Unidos, com o objetivo de discutir, junto à comunidade de pesquisa biomédica, a concretização efetiva do acesso aberto à produção científica. (ARAYA; VIDOTTI, 2010, p. 124).

9 A Declaração de Berlim sobre acesso livre ao conhecimento nas Ciências e Humanidades foi realizada em outubro de 2003, após uma conferência organizada pela Sociedade Max Planck e tem o objetivo de promover a internet como instrumento a serviço do conhecimento científico global e do pensamento humano. (ARAYA; VIDOTTI, 2010, p. 125).

10 A Declaração de Haia foi elaborada em dezembro de 2014, em um evento promovido pela Ligue de Bibliothèques Européenes de Recherche - LIBER, com o objetivo de se criar condições para uma prática de investigação mais responsável, reformar a legislação existente, desenvolver políticas de acesso aberto e criar infraestruturas por forma a que os benefícios destes instrumentos possam ter um impacto positivo na sociedade. (CORREIA, 2016).
} 
Esse mesmo autor destaca, também, algumas vantagens que o acesso aberto proporciona, como "maior rapidez na disseminação da literatura científica publicada nos repositórios de acesso livre, na visibilidade dos trabalhos publicados e no impacto dos resultados com ampliação das possibilidades de citação por outros autores". (KURAMOTO, 2006).

Outro grande passo foi dado quando o Governo Federal do Brasil decidiu, em 2000, arcar com os custos e disponibilizar o Portal de Periódicos da Capes ${ }^{11}$, um instrumento de política pública para subsidiar o acesso ao conhecimento científico. O Portal constitui-se hoje em um dos maiores acervos mundiais nesse setor e é atualmente o principal mecanismo para o apoio bibliográfico às atividades de pesquisa no Brasil. (CAPES, 2010). Outra importante ação do Governo é a participação do Instituto Brasileiro de Informação em Ciência e Tecnologia - IBICT - no apoio à disseminação do uso de arquivos/repositórios de acesso aberto.

Após o lançamento do manifesto, o IBCT implantou ações visando construir repositórios institucionais com a finalidade de ser depositário da produção científica dos pesquisadores universitários e de institutos de pesquisas nacionais, isto é, implantar a Via Verde. (KURAMOTO, 2014).

Prado (2014) esclarece que a Via Verde e a Via Dourada foram criadas por Stevan Harnad, principal líder do Movimento de Acesso Aberto no mundo, como ações para promover o acesso livre à produção científica.

Costa e Leite (2016, p. 34) definem essas estratégias da seguinte forma:

A Via Verde visa desenvolver repositórios de acesso aberto digitais a partir dos quais as publicações ou trabalhos aceitos para publicação são distribuídos.

A via Dourada incentiva a publicação acadêmica em revistas científicas de acesso livre, que poderiam ser acessadas livremente por parte da comunidade científica mundial sem a necessidade de adquiri-las.

Segundo Rodrigues e Oliveira (2012), ao mesmo tempo em que tem aumentado o número de títulos de periódicos, têm crescido também, principalmente na última década, estudos sobre periódicos digitais. Isto gerou um debate sobre a Via Verde (depósito de artigos

11 O Portal foi criado em 2000, no âmbito do Programa de Apoio à Aquisição de Periódicos Eletrônicos (PAAP), e gerido pela Coordenação de Aperfeiçoamento de Pessoal de Nível Superior (CAPES). 
já publicados em periódicos, em repositórios temáticos ou institucionais) e a Via Dourada (periódicos em acesso aberto), dando origem a novos modelos de publicação. Porém, Brown (2010), apud Rodrigues e Oliveira (2012), ressalta que esse debate que tem sido aquecido pela paixão, provém de contextos diferenciados, demandando assim estudos que sejam baseados em evidências. (Grifo nosso).

Chan e Costa (2005), citados por Costa e Leite (2016), destacam que é primordial o conhecimento e acesso à ciência e tecnologia "para reduzir os problemas dos países em desenvolvimento, como é o caso dos países latino-americanos, devido ao baixo investimento em pesquisa e as dificuldades de acesso à literatura internacional por causa do alto custo de assinaturas dos periódicos".

Em outubro de 2013, o DOAJ12, levantou dados que afirmaram o Brasil como segundo país com maior número de periódicos de acesso aberto. Os motivos que levaram o país a essa classificação são diferentes de outras regiões (América do Norte e Europa), pois as produções científicas no Brasil já possuem o livre acesso, sem a interferência de grandes editores comerciais. Essas inciativas trazem mais oportunidades para uma maior disseminação da produção científica. (ALPERIN; FISHMAN; WILLINSKY, 2008).

Para Bjork (2007), são muitos os argumentos a favor e contra o acesso aberto. Alguns afirmam que é moralmente errado grandes editoras terem o monopólio do acesso, obtendo lucros excessivos, sendo que a produção foi - na sua maioria - financiada pelos governos.

Kuramoto (2006, p. 92) ressalta que

As pesquisas científicas, em sua maioria, são financiadas pelo Estado, portanto, com recursos públicos. Do ponto de vista ético, os resultados dessas pesquisas deveriam ser de livre acesso. [No entanto, o que ocorre é que] o pesquisador ou qualquer outro cidadão, para ter acesso àquilo que foi produzido com o apoio do Estado, precisará pagar pela assinatura de uma publicação científica.

Outros autores defendem que os lucros sejam utilizados para apoiar as sociedades científicas e a utilização das receitas para apoiar outras revistas. Já os professores pesquisadores estão preocupados com o aumento de seus custos no modelo de autor-pagador.

\footnotetext{
12 Directory of Open Access Journals é um website que lista os periódicos de acesso aberto, criado em 2003 pela Lund University, Sweden e mantido pelo Infrastructure Services for Open Access (IS4OA). (DIRECTORY OF OPEN ACCESS JOURNALS, 2016, tradução nossa). www.doaj.org.
} 
Ainda sob a ótica de Bjork (2007), embora uma série de estudos empíricos sobre os efeitos econômicos de acesso aberto tenham sido realizados, é difícil comparar os resultados de tais estudos, uma vez que são muitas vezes medidos os diferentes aspectos do processo global. Assim, o autor defende a necessidade de estruturar modelos de processo de comunicação científica em geral que possam ser usados como base para comparação e integração dos resultados de diferentes estudos.

Em sua maioria, as editoras não apoiam o acesso livre. Mueller (2006) explica que para justificarem-se afirmam que estão protegendo o autor e a integridade do texto. Os editores visam o retorno financeiro que vem das vendas, ao contrário dos pesquisadores, que têm como retorno o reconhecimento e a reputação que alcançam com as publicações, ocasionando o recebimento de promoções, aumento de salários, convites ou bolsas para pesquisa. (WILLINSKY, 2002, apud MUELLER, 2006).

Harnard (1998), citado por Mueller (2006), argumenta que "o autor não teme roubo do texto (como temem as editoras), mas sim das ideias, de plágio".

Considerando a ciência da informação como via estratégica para a disseminação e aquisição coletiva e/ou individual de conhecimento, os profissionais da informação precisam refletir se prosseguirão defendendo a priorização às necessidades informacionais de seus usuários ou se cederão à mercantilização da informação e da cultura.

Percebe-se, pelas falas nos ambientes profissionais (bibliotecas, salas de aula e eventos científicos), que há certo consenso no pensamento dos profissionais da informação sobre a importância em disponibilizar a produção científica abertamente e sem restrições, sendo que uma das tarefas atuais é o convencimento aos autores e editores dos principais periódicos da área em usar essas ferramentas.

O pensamento de Willinsky (2006) parece retratar os sentimentos dos profissionais da informação, "se o conhecimento é qualificado, o mundo merece conhecê-lo sem ter de pagar por isso".

Rodrigues e Oliveira (2012, p. 6) entendem que os "periódicos científicos de acesso aberto beneficiam a sociedade como um todo, eliminando as barreiras de preço dos periódicos aos leitores e tornando a comunicação entre os pesquisadores mais rápida".

Neste sentido, em prol do benefício da sociedade, cabe aos bibliotecários buscar maior participação da sociedade civil organizada, instituições de ensino e pesquisa, sociedades científicas, editores 
científicos e das agências de fomento, gerando espaços de discussões que possam contribuir para aperfeiçoamento do sistema de acesso aberto, bem como defender mecanismos de controle social e transparência sobre as políticas públicas ligadas ao tema.

\section{O CONFLITO ENTRE ACESSO ABERTO À INFORMAÇÃO E DIREITO AUTORAL}

É sabido que a internet revolucionou a forma de disponibilizar e recuperar a informação. Diante da facilidade que proporciona, surgiu a possibilidade de tornar pública a produção científica em grande escala, que além de permitir o conhecimento e o acesso a inúmeras obras, facilitou a divulgação das produções científicas entre os pares.

O acesso digital às obras foi ampliado em virtude da facilidade de utilização desse meio. Dessa forma, ocasionou o aumento da necessidade de proteção dos direitos dos autores, em consequência das divulgações das obras. No entanto, Carboni (2005) entende que há a necessidade de garantir que essas produções científicas estejam ao alcance de todos.

Para muitos usuários, conforme explicam Peralta, Silva e Teruya (2011, p. 124), os conteúdos disponibilizados na rede possibilitaram o contato com obras de diferentes localidades e há uma demanda desses usuários por alternativas de uso que não sejam taxadas de violadoras de direitos de terceiros.

Ao mesmo tempo em que abriu novas possibilidades, o acesso livre também colidiu com alguns conceitos do direito do autor. Gandelman (2001, p. 182) cita:

- A extrema facilidade de se produzirem e distribuírem cópias não autorizadas de textos, música, imagens:

- A execução pública de obras protegidas, sem prévia autorização dos titulares;

- A manipulação não autorizada de obras originais digitalizadas, "criando-se" verdadeiras obras derivadas;

- Apropriação indevida de textos e imagens oferecidos por serviços on-line para distribuição de material informativo para clientes.

O autor alerta que "se os titulares de direitos autorais não forem remunerados devidamente, corremos o risco eminente de que não se criem ou produzam novas obras num futuro próximo".

O Acesso Aberto (AA) ou Acesso Livre é a disponibilização online e sem limitações dos resultados de prática científica, ou seja, 
da produção científica. O Acesso Aberto pode ser aplicado a todos os tipos de publicações científicas com ou sem a revisão por pares.

O Acesso Aberto grátis é aquele que se refere ao acesso online gratuito, e o livre se refere ao acesso online gratuito com alguns direitos adicionais de utilização. Os direitos de utilização adicionais são geralmente concedidos mediante a utilização de licenças Creative Commons (CC). ${ }^{13}$

As licenças do modelo Creative Commons são uma forma de não infringir as leis de direito autoral, flexibilizando o acesso às produções intelectuais por meio de licenças públicas que possibilitam o acesso livre às obras por qualquer pessoa. Desta maneira, o autor permite o acesso irrestrito de sua obra intelectual, podendo a mesma ser distribuída, copiada e utilizada livremente, protegendo o usuário quanto às punições intercorrentes dos direitos de autoria.

As licenças podem ser utilizadas para qualquer obra e procuram atender às demandas e interesses dos autores, criadores ou detentores de direitos, conforme explica Lemos (2005). São descritas em três níveis para que todos possam compreender seu conteúdo: a versão para leigos, onde qualquer pessoa entenda a licença e os direitos que ela concede; outra para advogados, descrita em termos jurídicos; e em nível técnico, transcrita em linguagem de computador. (CREATIVE COMMONS, 2016).

Os seis principais tipos de licenças são definidos segundo o $\mathrm{CC}$, da seguinte forma:

- Atribuição: Permite que outros distribuam, remixem, adaptem e criem a partir do seu trabalho, mesmo para fins comerciais, desde que Ihe atribuam o devido crédito pela criação original. É a licença mais flexível de todas as licenças disponíveis. É recomendada para maximizar a disseminação e uso dos materiais licenciados.

- Atribuição-Compartilha Igual: Permite que outros remixem, adaptem e criem a partir do seu trabalho, mesmo para fins comerciais, desde que the atribuam o devido crédito e que licenciem as novas criações sob termos idênticos. Esta licença costuma ser comparada com as licenças de software livre e de

${ }^{13}$ Creative Commons foi fundada em 2001 com o generoso apoio do Centro para o Domínio Público e do William and Flora Hewlett Foundation. É dirigida por um Conselho de Administração composto de líderes, especialistas em educação, técnicos, juristas, investidores, empresários e filantropos. É uma organização sem fins lucrativos, que permite o compartilhamento e o uso da criatividade e do conhecimento através de licenças jurídicas gratuitas. (CREATIVE COMMONS, 2016). https://creativecommons.org. 
código aberto "copyleft". Todos os trabalhos novos baseados no seu terão a mesma licença, portanto quaisquer trabalhos derivados também permitirão o uso comercial. Esta é a licença usada pela Wikipédia e é recomendada para materiais que seriam beneficiados com a incorporação de conteúdos da Wikipédia e de outros projetos com licenciamento semelhante.

- Atribuição-Sem Derivações: Permite a redistribuição, comercial e não comercial, desde que o trabalho seja distribuído inalterado e no seu todo, com crédito atribuído a você.

- Atribuição-Não Comercial: Permite que outros remixem, adaptem e criem a partir do seu trabalho para fins não comerciais, e embora os novos trabalhos tenham de lhe atribuir o devido crédito e não possam ser usados para fins comerciais, os usuários não têm de licenciar esses trabalhos derivados sob os mesmos termos.

- Atribuição-Não Comercial-Compartilha Igual: permite que outros remixem, adaptem e criem a partir do seu trabalho para fins não comerciais, desde que atribuam a você o devido crédito e que licenciem as novas criações sob termos idênticos.

- Atribuição-Sem Derivações-Sem Derivados: Esta é a mais restritiva das seis licenças principais, só permite que outros façam download dos seus trabalhos e os compartilhem desde que atribuam crédito a você, mas sem que possam alterá-los de nenhuma forma ou utilizá-los para fins comerciais. (CREATIVE COMMONS, 2016).

Ainda segundo o Creative Commons, os clientes que desejam colocar um trabalho no domínio público, especificando que renunciam a todos os direitos, podem fazê-lo, utilizando a Marca de Domínio Público. Esse modelo de licenciamento cria, de acordo com Lemos (2005, p. 83),

Uma alternativa ao direito da propriedade intelectual tradicional, fundada de baixo para cima, isto é, em vez de criadas por lei, elas se fundamentam no exercício das prerrogativas que cada indivíduo tem, como autor, de permitir o acesso às suas obras e a seus trabalhos, autorizando que outros possam utilizá-los e criar sobre eles. Por isso, o direito autoral, caracterizado como um grande "Não!", começa a se transformar em razão desses "microatores", que passam a ter canais para indicar ao mundo que preferem o caminho do "Sim". Um "Sim" que tenta recuperar a promessa libertária original da internet e da tecnologia digital de emancipação criativa, e que faz do direito não um instrumento de preservação do passado, mas de transição para o futuro.

Frente ao atual debate sobre direitos autorais, e como visto na exposição acima, cabe aos profissionais da informação, dentre eles 
os bibliotecários, participar ativamente dessa discussão e buscarem um posicionamento político que melhor respalde sua atuação profissional e seu papel de mediadores na sociedade da informação.

\section{ACESSO ABERTO E DIREITOS AUTORAIS: impactos para os bibliotecários e demais profissionais da informação}

O que é ser bibliotecário hoje?

Esta pergunta sugere uma resposta tão flexivel quanto as adaptações que este profissional deve exercer para direcionar o sucesso de sua carreira. (SILVA, 2005).

A maior parte dos profissionais da informação, dentre eles os bibliotecários, vem acompanhando e buscando alternativas para sua atuação profissional frente ao avanço das tecnologias e a influência das mesmas junto aos seus usuários. $\mathrm{Na}$ área social, estes mesmos profissionais passam a adaptar seus serviços aos debates sobre multiculturalismo, biblioteca escolar, diversidade cultural, inclusão digital, acessibilidade e usabilidade aos deficientes. Ou seja, os profissionais devem preocupar-se, cada vez mais com o acesso social à informação, ao conhecimento e à cultura em todos os níveis de sua intervenção. Nestes diversos âmbitos, o acesso à informação científica e as leis de direitos autorais passam a influenciar diretamente, mesmo que às vezes de forma velada, e a dificultar, até mesmo impedir, serviços oferecidos pelos profissionais da informação, sobretudo os bibliotecários, aos seus usuários. Seguem alguns exemplos:

a) Softwares e serviços de bases de dados, utilizados pelas bibliotecas universitárias

Com o objetivo de atender aos seus pesquisadores e manterem-se com boa conceituação junto à sociedade e aos órgãos que as avaliam institucionalmente, as universidades compram softwares e pagam significativos recursos financeiros para o acesso a produções científicas nacionais e internacionais das mais diversas áreas do conhecimento contidas em Bases de Dados privadas. Em sua maioria, as pesquisas que compõem tais bases são financiadas com recursos públicos.

Diferentemente da aquisição de revistas cientificas impressas, que ao serem compradas são facilmente incorporadas ao acervo das instituições, as Bases de Dados são apenas licenças, restringindo diversos serviços antes oferecidos com a versão 
impressa, como a comutação - serviço de solicitação de fotocópias e/ou empréstimo de documentos - entre bibliotecas -, como também limitação de acessos e impressões das mesmas. Segundo Story, Halbert e Darch (2006, p. 104),

\begin{abstract}
En las bibliotecas de aquellos países menos desarrollados con una moderna infraestructura de ICT (Infraestructuras Comunes de Telecomunicaciones), tales como Suráfrica, Brasil o la India, los problemas surgen cada vez más a partir de las capas de protección de la propiedad intelectual que se superponen al derecho de autor o copyright. Estas incluyen los términos y condiciones de los contratos de acceso a las bases de datos comerciales (denominados normalmente licencias), así como los dispositivos tecnológicos tanto de software como de hardware y las nuevas leyes que criminalizan cualquier clase de elusión de dichos dispositivos (leyes antielusión). Este problema afecta todas las bibliotecas del mundo, pero tiene un impacto desproporcionado sobre los países en vías de desarrollo, ya que probablemente no dispongan de fondos para pagar licencias suplementarias, y puede que no tengan capacidad para negociar mejores condiciones de licencia o hacer lobby (es decir, cabildear, N. del E.) para conseguir mejores leyes de propiedad intelectual.
\end{abstract}

\title{
b) Redes sociais e compartilhamento
}

Jovens no mundo todo trocam seus arquivos de música, filmes, vídeos, pelo computador. Como criminalizar toda uma cultura nova, do compartilhamento, da duplicação, da difusão? Já em 2009, Araya e Vidotti registram que, segundo a Federação Internacional da Indústria Fonográfica, $95 \%$ dos downloads são ilegais. Os autores apresentam, também, dados do lbope/NetRatings da época, onde $46 \%$ dos internautas brasileiros acessam sites e serviços de downloads ilegais. Registram, ainda, que segundo a Federação do Comércio do Estado do Rio de Janeiro (Fecomércio-RJ), apenas 5\% dos brasileiros não recorrem à pirataria por medo de punição. (ARAYA; VIDOTTI, 2009, p. 47).

O que fazer quando a lei entra em conflito direto com a atuação do bibliotecário e o seu papel de disseminador da informação? Os bibliotecários e outros profissionais da informação, que veem nascer e crescer uma nova geração de usuários virtuais e digitais, que ampliam as redes sociais da internet, que criam, compartilham informações, músicas, filmes entre outros, de forma ágil e fácil, também veem uma ampliação das leis de direitos de autor e são apontados com o dever moral de vigiar o cumprimento destas leis em seus espaços de trabalho. A maioria dos debates sobre o assunto apontam apenas as 
consequências e cuidados a serem tomados para não infringir as leis. Mas o que está ocorrendo em nível nacional e internacional é o questionamento dessas leis e da forma como elas estão sendo utilizadas. Quem está errado, os usuários, os profissionais que lidam com a informação ou a legislação?

\section{c) Cópias para fins educativos e acesso a deficientes}

Diferentemente de outros países, a legislação brasileira sobre direitos autorais permite, embora não quantifique, cópias de 'pequenos trechos' de obras para uso privado do copista ${ }^{14}$, desde que feita por este sem intuito de lucro. Tal trecho tem sido usualmente interpretado como para "fins educativos".

Também há brechas, no Brasil, para a tradução de obras para o Braile ${ }^{15}$. No entanto, a abertura para a aquisição de obras para fins educativos e acesso a deficientes termina aí. $\mathrm{E}$ isto prejudica principalmente as instituições públicas de ensino, na perspectiva de assegurarem aos seus usuários acesso à informação, à cultura e ao conhecimento, pois não possuem a mesma capacidade financeira das instituições privadas de ensino para aquisição de obras protegidas.

Tais situações perpassam o cotidiano de todo profissional da informação. Resta saber se, diante das leis de direitos autorais e seus impactos sobre o exercício de profissões e mesmo sobre as necessidades dos usuários, serão ou não agentes passivos no cumprimento de tais leis. Se a opção for a de ter voz ativa sobre este processo, o horizonte de debate e proposição de alternativas será promissor.

\section{ASPECTOS DA METODOLOGIA DA PESQUISA}

A presente investigação foi classificada como exploratóriadescritiva e, quanto à análise dos dados, caracterizada como quali-quantitativa, tendo a coleta de dados ocorrido entre os meses de fevereiro e setembro de 2017. Participaram da

\footnotetext{
${ }^{14}$ Lei 9.610/1998 - Capítulo IV - Das Limitações aos Direitos Autorais - Art. 46. "Não constitui ofensa aos direitos autorais: II - a reprodução, em um só exemplar, de pequenos trechos para uso privado do copista, desde que feita por este, sem intuito de lucro". (BRASIL, 1998).

${ }^{15}$ Lei 9.610/1998 - Capítulo IV - Das Limitações aos Direitos Autorais - Art. 46. "Não constitui ofensa aos direitos autorais: I - a reprodução: d) de obras literárias, artísticas ou científicas, para uso exclusivo de deficientes visuais, sempre que a reprodução, sem fins comerciais, seja feita mediante o sistema Braille ou outro procedimento em qualquer suporte para esses destinatários". (BRASIL, 1998).
} 
pesquisa 53 bibliotecários (as), registrados no Conselho Regional de Biblioteconomia de Santa Catarina - CRB 14 ${ }^{\mathrm{a}}$.

Os dados foram coletados por meio questionário eletrônico, com 14 perguntas fechadas. Salienta-se que as questões de números 7 e 14 tinham a possibilidade de complementação de forma livre (aberta). Parte do questionário foi estruturado com base no instrumento de coleta elaborado por Torrado (2012), em sua tese de doutorado.

\section{RESULTADOS E DISCUSSÃO}

Os resultados do estudo foram divididos em duas sessões, a primeira se preocupa com a Lei 9.610, de 1998 - Lei Brasileira de Direitos Autorais - e a segunda com o Movimento de Acesso Aberto.

Com relação à Lei Brasileira de Direitos Autorais, 47,2\% dos bibliotecários afirmaram conhecê-la pouco e 9,4\% afirmaram ignorála por completo. Por esta razão, foram direcionados para responderem somente a segunda parte do questionário. Desta forma, 48 sujeitos responderam as questões inerentes à Lei. Disseram conhecer a lei, $37,7 \%$ dos respondentes.

A maior parte dos bibliotecários pesquisados $(68,8 \%)$ têm conhecimento de que, conforme o Art. 18 da Lei 9.610, "A proteção aos direitos de que trata esta Lei independe de registro".

Quando questionados sobre o tempo que leva para uma obra passar a ser de domínio público, ninguém respondeu à questão de forma correta, o que demonstra um total desconhecimento de um aspecto considerado por esta pesquisadora como sendo básico. Conforme o Art. 41 da Lei 9.610, "Os direitos patrimoniais do autor perduram por setenta anos contados de $1^{\circ}$ de janeiro do ano subsequente ao de seu falecimento, obedecida a ordem sucessória da lei civil".

Quase a totalidade dos respondentes tinha conhecimento de que "ao autor são dados os direitos morais e patrimoniais sobre a obra que criou". Na opção "tratando-se de obra anônima ou pseudônima, caberá a quem publicá-la o exercício dos direitos patrimoniais do autor", houve quase que um empate entre os sujeitos que responderam que conheciam e os que não conheciam. Quarenta bibliotecários confirmaram que conheciam o fato de que diante da "utilização da obra, para a inclusão em base de dados, o armazenamento em computador, a microfilmagem e as demais formas de arquivamento do gênero, depende de autorização prévia e expressa do autor". 
Com o intuito de se conhecer a realidade dos bibliotecários no que se refere ao cumprimento da lei brasileira de direitos autorais, questionou-se quais eram as suas práticas em relação à reprografia/reprodução; orientação ao usuário; atividades culturais; e bases de dados.

A prática dos bibliotecários catarinenses em relação reprografia/reprodução parece estar em consonância com a lei. Os resultados demonstram que a reprodução de pequenos trechos, para uso privado do copista, sem lucro para a biblioteca, foi a prática mais comum realizada nas bibliotecas. Vale salientar que, segundo o Art. 46 da Lei 9.610, não constitui ofensa aos direitos autorais "Il - a reprodução, em um só exemplar de pequenos trechos, para uso privado do copista, desde que feita por este, sem intuito de lucro". Da mesma forma, não constitui ofensa aos direitos autorais "I - a reprodução: [...] d) de obras literárias, artísticas ou científicas, para uso exclusivo de deficientes visuais, sempre que a reprodução, sem fins comerciais, seja feita mediante o sistema Braille ou outro procedimento em qualquer suporte para esses destinatários".

Em relação à orientação ao usuário, nota-se que a citação de autoria e referências bibliográficas são bem orientadas pelos bibliotecários, pois 42 bibliotecários pesquisados responderam que orientam os usuários a indicar o autor e obra quando usarem passagens de qualquer obra, e 41 orientam que, na reprodução de notícia ou de artigo informativo, publicado em periódicos, deve ser feita menção ao nome do autor e da publicação de onde foram transcritos.

No que diz respeito às atividades culturais, a prática de representação teatral e/ou a execução de música, sem fins comerciais ou lucrativos, ainda parece ser tímida nas bibliotecas, sendo que menos da metade dos respondentes registraram a realização deste tipo de atividade em seus locais de trabalho. Um ponto favorável é que 45 bibliotecários não costumam permitir a representação teatral e a execução musical, com lucro para a biblioteca, ou seja, não infringem a Lei de Direitos Autorais. O ponto preocupante é que 3 apontaram que permitem apresentações que visam lucro.

No que cabe às bases de dados, o Art. $7^{\circ}$ da Lei 9.610 estabelece que "São obras intelectuais protegidas as criações do espírito, expressas por qualquer meio ou fixadas em qualquer suporte, tangível ou intangível, conhecido ou que se invente no futuro, tais como: [...] XIII - as coletâneas ou compilações, antologias, enciclopédias, dicionários, bases de dados e outras 
obras que, por sua seleção, organização ou disposição de seu conteúdo, constituam uma criação intelectual". (Grifo nosso).

Para não haver violação da LDA, as formas de disponibilização dos dados/obras aos usuários dependem das cláusulas contratuais, que devem ser observadas com atenção e seguidas à risca.

Além das bases de dados, ressalta-se que, segundo o Art. 29, "Depende de autorização prévia e expressa do autor a utilização da obra, por quaisquer modalidades, tais como: IX - a inclusão em base de dados, o armazenamento em computador, a microfilmagem e as demais formas de arquivamento do gênero". Disto compreendese que, além da base de dados, as próprias obras/documentos que as compõem, também estão protegidas por lei.

No presente estudo, $70,8 \%$ dos bibliotecários responderam que "Não" disponibilizam aos usuários informações provenientes de bases de dados assinadas independente das cláusulas contratuais da base, mas $29,1 \%$ responderam que "Sim", disponibilizam. Para agravar a situação, 4 (8,3\%) responderam que "Disponibilizam cópias das bases de dados assinadas pela biblioteca onde trabalha às bibliotecas carentes de sua região". Mesmo sendo um percentual pequeno, este resultado é preocupante, pois demonstra a violação das leis vigentes, provavelmente por desconhecimento da legislação. Ainda sobre as bases de dados, $72,9 \%$ dos respondentes afirmam que "Não" faz parte de sua rotina conhecer em profundidade cada contrato de compra das bases de dados da biblioteca.

Em relação ao direito patrimonial do titular sobre uma base de dados e seus direitos exclusivos na alternativa:"Autorizar ou proibir sua reprodução total ou parcial, por qualquer meio ou processo", $79,1 \%$ dos participantes da pesquisa afirmaram ter conhecimento prévio desta premissa. Em relação à autorização ou proibição da tradução, adaptação, reordenação ou qualquer outra modificação, $72,9 \%$ dos bibliotecários pesquisados conheciam o contexto e $27,1 \%$ não conheciam.

Outro aspecto elencado se refere à autorização ou proibição da distribuição do original ou cópias da base de dados ou a sua comunicação ao público. Neste caso $77 \%$ dos participantes desta pesquisa afirmaram conhecer este quesito e $23 \%$ disseram não conhecer. As respostas deste último aspecto parecem reforçar as respostas dadas na questão anterior, pois quando $23 \%$ dos bibliotecários dizem desconhecer que cabe ao titular do direito patrimonial sobre uma base de dados o direito exclusivo de autorização ou proibição da distribuição do original ou cópias da 
base de dados, isto parece Ihes dar certa "liberdade" (por ignorância, no sentido de ignorar/desconhecer o fato) para disponibilizar aos usuários informações provenientes de bases de dados assinadas, independente das cláusulas contratuais da base $(29,1 \%)$ e ainda pior, para disponibilizar cópias das bases de dados assinadas pela biblioteca onde trabalha, para as bibliotecas carentes de sua região $(8,3 \%)$. O resultado é preocupante, pois demonstra 0 desconhecimento e violação das leis vigentes.

Para $66,7 \%$ dos bibliotecários pesquisados a LDA nunca atrapalhou seu trabalho junto aos usuários da biblioteca, mas 33,3\% dos profissionais já sentiram esta dificuldade. As dificuldades recaem principalmente em dois aspectos: a) em relação à cópia/fotocópia/reprodução/impressão; b) em relação à obra estar disponível na internet ou em PDF, mas não estar autorizada pelo autor a sua disponibilização (protegida pelos direitos autorais). As dificuldades com a reprodução das obras é o fator "dificultador" mais importante nos relatos.

A maioria dos bibliotecários $(89,6 \%)$ tem conhecimento de que as sanções de ordem civil são estabelecidas na LDA. Estas sanções são estabelecidas nos Arts. 101 a 110 da Lei, sendo que se aplicam sem prejuízo das penalidades cabíveis. Destaque-se, ainda, que as violações dos direitos autorais e suas respectivas penalidades estão previstas no artigo 184 do Código Penal Brasileiro.

A segunda parte do questionário envolve as questões relativas ao Movimento de Acesso Aberto e, num primeiro momento, se preocupa em investigar o grau de adesão dos bibliotecários a este movimento. Neste sentido, $37,7 \%$ dos pesquisados se disseram com "adesão regular/média", 34\% com "extrema adesão" e 13,2\% com "muita adesão", que somados representam $84,9 \%$ da amostra. Não se sentem "aderidos" ou com pouca adesão 15,1\% dos bibliotecários.

Ao verificar-se a frequência de busca a documentos científicos disponibilizados por acesso aberto, encontrou-se um empate, com 14 ocorrências cada $(26,4 \%)$, as buscas "quinzenais/semanais" e as "diárias", seguidas das buscas "bimestrais/mensais", com $22,6 \%$. Oito $(15,1 \%)$ dos pesquisados nunca fazem buscas para os usuários oferecendo documentos de acesso aberto. Considera-se que há uma boa frequência de uso dos documentos em acesso aberto pelos bibliotecários catarinenses e pode-se afirmar que estes profissionais têm a cultura de utilizar documentos de acesso livre.

Em relação às licenças do tipo Copyleft, 52,8\% dos respondentes entendem que são aquelas em que o autor decide 
quais são os direitos aos quais quer renunciar e quais devem permanecer, ao passo que $24,5 \%$ afirmam que o autor renuncia a todos os direitos patrimoniais, mas os direitos morais permanecem. O restante, que equivale a $22,6 \%$, crê que o autor renuncia a todos os direitos autorais. De acordo com os resultados, os bibliotecários catarinenses parecem ter noção do que tratam as licenças Copyleft.

Apesar dos bibliotecários afirmarem, em 37,7\% dos casos, que têm uma adesão regular e 34\% extrema adesão ao movimento de acesso aberto e da frequente busca por material científico de acesso aberto, $66 \%$ dos bibliotecários relatam que não sabem como encontrar conteúdos com licença tipo Copyleft para disponibilizar aos usuários. Somente $34 \%$ dos bibliotecários afirmaram que sabem encontrar obras disponíveis com tal característica. A partir dos resultados obtidos, parece haver uma incongruência nas respostas fornecidas. Neste momento a pesquisadora faz uma reflexão e uma autocrítica, talvez devesse ter incluído explicitamente as licenças Creative Commons, assim como fez com a Copyleft no enunciado da questão, ou ter elaborado um enunciado de forma ampla, com o indicativo de "licenças de acesso livre". O enunciado da questão poderia ter sido mais claro.

Com relação ao conhecimento sobre a edição de documentos sob licença Creative Commons, o desconhecimento dos bibliotecários é grande, sendo que $75,5 \%$ dos questionados afirmaram que não sabem orientar seus usuários neste sentido.

Considerando o conflito de interesses e opiniões em relação ao Movimento de Acesso Livre e a lei de direitos autorais, a opinião que prevaleceu com $64,2 \%$, foi a "Favorável que prevaleça o acesso aberto à informação científica"; $17 \%$ não souberam opinar e 11,3\% manifestaram posição "Favorável que prevaleça a legislação brasileira de direitos autorais". Outras opiniões foram registradas, cada uma delas representou $1,8 \%$ do total geral de respostas.

\section{CONSIDERAÇÕES FINAIS}

Entende-se que o estudo foi exitoso no que se refere a averiguar o nível de conhecimento que os bibliotecários de Santa Catarina possuem acerca da Lei Brasileira de Direitos Autorais e o grau de adesão ao Movimento de Acesso Aberto à informação científica. Observou-se que o grau de conhecimento relativamente à lei é muito variado, sendo alguns aspectos bem conhecidos e outros totalmente ignorados. Em síntese, acerca da Lei Brasileira de Direitos Autorais, a maior parte dos bibliotecários tem conhecimento 
de que a proteção aos direitos dos quais trata esta lei independe de registro e de que ao autor são dados os direitos morais e patrimoniais sobre a obra que criou. Há um desconhecimento generalizado sobre o tempo que leva para uma obra passar a ser de domínio público. A prática dos bibliotecários catarinenses em relação reprografia/reprodução parece estar em consonância com a lei, embora relatem que enfrentam dificuldades em relação às imposições legais. A orientação ao usuário no que se refere à citação de autoria e referências bibliográficas pode ser considerada adequada. As questões referentes às bases de dados e seus contratos não estão claras aos bibliotecários. A LDA não costuma atrapalhar o trabalho da maioria dos bibliotecários junto aos usuários da biblioteca, sendo que as dificuldades com a reprodução das obras é o fator mais citado pelos bibliotecários. A maioria dos pesquisados tem conhecimento de que as sanções de ordem civil são estabelecidas pela LDA.

De maneira geral, em se tratando do Movimento de Acesso Aberto, os resultados apontam que os bibliotecários de Santa Catarina se sentem aderidos ao Movimento, têm boa frequência de uso deste tipo de documento, sabem o que são licenças Copyleft, mas não sabem como encontrar conteúdos disponíveis sob este tipo de licenças e também não sabem orientar os usuários das bibliotecas a editar documentos com licenças Creative Commons. Em sua maioria, os bibliotecários de SC consideram mais importante que haja acesso livre a informação científica, do que a prevalência dos direitos autorais. Esta posição parece ser compreensível, visto que para estes profissionais a prioridade deve ser satisfazer as necessidades informacionais de seus usuários.

É possível que, se o mesmo instrumento de coleta de dados fosse aplicado a profissionais da área jurídica, o resultado fosse o oposto. Fica a sugestão de aplicação e futura comparação dos resultados.

Entende-se que se os bibliotecários de Santa Catarina fechassem os olhos para os debates que estão ocorrendo sobre acesso aberto e direitos autorais e abandonassem a luta pela democratização do saber, estariam se comportando tal qual um avestruz diante de uma situação de perigo. Ao contrário, o momento exige participação ativa de aprofundamento do debate e tomada de posição política diante dos desafios que estão colocados. E tais desafios não se resumem aos aspectos meramente corporativos que tal debate encerra. $O$ centro dos questionamentos é a garantia do direito social à informação. 
Uma coisa parece ser unanimidade: é necessário encontrar uma forma de garantir o direito individual do autor de proteção à sua obra, sem ferir o direito da sociedade ao acesso à informação, que tem fundamental importância para o desenvolvimento econômico, cultural e tecnológico de qualquer nação.

\section{REFERÊNCIAS}

ABADAL, E. et al. Open access in Spain. In: ANGLADA, L; ABADAL, E. (Eds.). Open access in Southern European countries. Madrid: FECYT, 2010.

ALPERIN, J. P.; FISCHMAN, G. E.; WILLINSKY, J. Open access and scholarly publishing in Latin America: ten flavours and a few reflections. Liinc em Revista, Rio de Janeiro, v.4, n.2, set. 2008. Disponível em: <http://revista.ibict.br/liinc/article/viewFile/3165/2831>. Acesso em: 19 set. 2017.

ARAYA, E. R. M.; VIDOTTI, S. A. B. G. Criação, proteção e uso legal de informação em ambientes da World Wide Web. [online]. São Paulo: Editora UNESP, 2010. 144p. Disponivel em: <https://books.google.com.br/books>. Acesso em: 22 maio 2016.

. Direito autoral e tecnologias de informação e comunicação no contexto da produção, uso e disseminação de informação: um olhar para as licenças Creative Commons. Informação \& Sociedade, João Pessoa, v. 19, n. 3, set./dez. 2009.

BARRETO, A. de A. Uma história da ciência da informação. In: TOUTAIN, Lídia Maria Batista Brandão (Org.). Para entender a ciência da informação. Salvador: EDUFBA, 2012.

BJORK, B-C. A model of scientific communication as a global distributed information system. Information Research, v.12, 2007. Disponível em: <http://informationr.net/ir/12-2/paper307.html>. Acesso em: 25 jul. 2013.

BRASIL. Constituição (1988). Constituição da República Federativa do Brasil. Disponível em:

<http://www.planalto.gov.br/ccivil_03/Constituicao/Constituicao.htm>. Acesso em: 03 abr. 2016.

. Lei 9.610, de 19 de fevereiro de 1998. Lei de direitos autorais. Brasília, DF. Disponível em: <http://www.planalto.gov.br/ccivil_03/leis/L9610.htm>. Acesso em: 03 abr. 2016.

CARBONI, G. C. Conflitos entre direito de autor e direito de acesso ao conhecimento, à cultura e à informação. In: CONGRESSO BRASILEIRO DE CIÊNCIAS DA COMUNICAÇÃO - INTERCOM, 28. Rio de Janeiro, 2005. Anais... Rio de Janeiro: UERJ, 2005.

. Conflitos entre direitos do autor e liberdade de expressão, direito de livre acesso à informação e à cultura e direito ao desenvolvimento tecnológico. Revista da BPI, n. 85, p. 38, Nov/dez de 2006. 
CORAZZA, S., DUARTE, C. R. A pesquisa na educação física. Rev. Corpo \& Movimento. v. 1, n. 3, p. 30, out. 1984.

CORREIA, M. M. Declaração de Haia sobre a descoberta do conhecimento na era digital. Notícia BAD, publicado em 24 de abril de 2015. Disponível em: <http://www.bad.pt/noticia/2015/04/24/declaracao-dehaia-sobre-a-descoberta-do-conhecimento-na-era-digital/>. Acesso em: 29 set. 2016.

COSTA, M. P.; LEITE, F. C. S. L. Acesso aberto no mundo e na América Latina: uma revisão a partir do BOAl. Versão traduzida do artigo: Open Access in the world and Latin American: a review from the Budapest Open Access Initiative. Transinformação, v. 28, n. 1, p. 33-46, 2016. Disponível em: <http://basessibi.c3sl.ufpr.br/brapci/v/19544>. Acesso em: 15 maio 2016.

COSTA, Liliana Fátima Resende. Direitos autorais e acesso aberto à informação: pesquisa bibliográfica em busca de um consenso. 2016. Trabalho de Conclusão de Curso (Bacharelado em Biblioteconomia) Centro de Ciências Humanas e da Educação, Universidade do Estado de Santa Catarina, 2017. 44p.

EL DOSSIER copia/sur: problemas económicos, políticos, e ideológicos del copyright (derecho de autor) en el sur global. 2007. E-prints in library \& information Science [E-LIS repository]. Disponivel em: <http://eprints.rclis.org/11451/>. Acesso em: 20 jul. 2016.

GANDELMAN, Henrique. De Gutenberg à Internet: direitos autorais das origens à era digital. 5. ed. rev. e atual. Rio de Janeiro: Ed. Record. 2007.

GUENDON, J. Oldenburg's long shadow: librarians, research scientists, publishers, and the control of scientific publishing. Association of Research Libraries. 2001. Disponível em:

<http://www.arl.org/resources/pubs/mmproceedings/138guedon.shtml>. Acesso em: 28 abr. 2014.

KURAMOTO, H. L. Acesso livre: uma solução adotada em todo o globo; porém, no Brasil parece existir uma indefinição. Revista Eletrônica de Comunicação, Informação \& Inovação em Saúde, v. 8, n. 2, 2014. Disponível em: <http://basessibi.c3sl.ufpr.br/brapci/v/18822>. Acesso em: 04 maio 2016.

- Informação científica: proposta de um novo modelo para o Brasil. Ciência da Informação, v. 35, n. 2, p. 91-102, 2006. Disponível em: <http://basessibi.c3sl.ufpr.br/brapci/v/3938>. Acesso em: 03 maio 2016.

LEMOS, R. Direito, tecnologia e cultura. Rio de Janeiro: FGV, 2005.

LIMA, C. L. C. Definições analíticas para os segmentos produtores de bens simbólicos: uma breve análise. In: ENCONTRO DA ULEPIC - Brasil, economia Política da comunicação: interfaces sociais e acadêmicas do Brasil. 1. 2006. Niterói. Anais... RJ: UFF, 2006. 
LOURENÇO, C. de A. Automação em bibliotecas: análise da produção via Biblioinfo (1986-1994). In: WITTER, G. P. (Org.). Produção científica. Campinas: Átomo, 1997.

LUTA ENTRE DAVI E GOLIAS: HISTÓRIAS BÍBLICAS. Disponível em:<http://www.jw.org/pt/publicacoes/livros/Hist\%C3\%B3rias-

B\%C3\%ADblicas/Parte-4-Desde-o-primeiro-rei-de-Israel-at\%C3\%A9-ocativeiro-em-Babil\%C3\%B4nia/Hist\%C3\%B3ria-58-Davi-e-Golias/>. Acesso em: 13 abr. 2014.

MEADOWS, A J. A comunicação científica. Brasília. Briquet de Lemos, 1999.

MUELLER, Suzana Pinheiro Machado. A comunicação científica e o movimento de acesso livre ao conhecimento. Ciência da Informação, Brasília, v. 35, n. 2, p. 27-38, ago. 2006. Disponível em: <http://www.scielo.br/>. Acesso em: 9 maio 2016.

ORGANIZAÇÃO DAS NAÇÕES UNIDAS PARA A EDUCAÇÃO, A CIÊNCIA E A CULTURA. Declaração Universal Sobre A Diversidade Cultural. Unesco, 2001. Disponível em:

<http://www.unesco.org.br/areas/cultura/divcult/dcult/mostra documento>. Acesso em: 23 mar. 2014.

PERALTA, Patrícia Pereira; SILVA, Elizabeth Ferreira da; TERUYA, Dirceu Yoshikazu. Busca de consenso entre o direito do autor e o acesso à informação pelo público na rede de computadores: uma ótica dos tratados relativos ao direito autoral. Perspectivas em Ciência da Informação, Belo Horizonte, v. 16, n. 3, p.116-130, 2011. Disponível em: <http://www.brapci.ufpr.br/brapci/v/11456>. Acesso em: 25 abr. 2016.

PIMENTA, F. P. et al. O direito de autor no movimento de acesso livre e aberto, um estudo sob a ótica das editoras científicas. Ponto de Acesso, v. 9, n. 3, p.133-148, 2015. Disponível em: <http://www.brapci.ufpr.br/brapci/v/18631>. Acesso em: 21 maio 2016.

PRADO, Jorge Moisés Kroll do; SILVEIRA, Lúcia da; MACHADO, Raquel Bernadete. Movimento de acesso livre ao conhecimento científico e tecnológico. UDESC-PPGINFO, Florianópolis, 2014. $11 \mathrm{f}$. [Não publicado.]

REIS, R., et al. (Orgs.). Propriedade intelectual: agricultura, software, direito de autor, medicamentos: interfaces e desafios. In: SEMINÁRIO NACIONAL PROPRIEDADE INTELECTUAL: INTERFACES E DESAFIOS. Rede Brasileira pela Integração dos Povos (REBRIP). Anais... Rio de Janeiro: ABIA, 2007.

RODRIGUES, R. S.; OLIVEIRA A. B. Periódicos Científicos na América Latina: Títulos em Acesso Aberto Indexados no ISI e Scopus. Perspectivas em Ciência da Informação. 17, 2012 p. 76-99. 
ROSA, A. M. Direito de autor e direito de acesso: os livros eletrônicos, as bibliotecas públicas e o princípio de esgotamento. 2013. Repositório Científico de Acesso Aberto de Portugal. Disponível em: <https://repositorio-aberto.up.pt/bitstream/10216/74689/2/77299.pdf>.

Acesso em: 13 nov. 2017.

ROZADOS, H. B. F.; REIS, J. M. dos. Direito autoral e o livro eletrônico. Revista da Faculdade de Biblioteconomia e Comunicação da UFRGS, v. 20, n. 1, jan./jun. 2014. p. 32-46. Disponível em: $<$ http://seer.ufrgs.br/index.php/EmQuestao/article/view/38691>. Acesso em: 13 nov. 2017.

SANZ CASADO, Elías. Manual de estudios de usuarios. Madrid: Piramide, 1994. 279 p.

SAYÃO, Luis Fernando. Repositórios digitais confiáveis para a preservação de periódicos eletrônicos científicos. PontodeAcesso, Salvador, v.4, n.3, p. 68-94, dez 2010.

SIGNIFICADOS. Expressões em inglês. Significado de copyleft. Disponivel em: <https://www.significados.com.br/copyleft/>. Acesso em: 13 nov. 2017.

SILVA, F. C. C. Bibliotecários especialistas: guia de especialidades e recursos informacionais. Brasília: Thesauros, 2005.

SOUZA, M. N. A. et al. Acesso aberto à informação científica e direito autoral: ações e contradições. Encontros Bibli: Revista Eletrônica de Biblioteconomia e Ciência da Informação, v. 17, n. 2, p. 55-64, 2012. Disponível em: <http://www.brapci.ufpr.br/brapci/v/16482>. Acesso em: 09 abr. 2016.

STORY, A.; HALBERT, D.; DARCH, C. (ed.). The Copy/South Dossier: issues in the economics, politics and ideology in the global South. Canterbury: The CopySouth Research Group, 2006. 210p. Disponivel em: <http://www.copysouth.org> (em inglês e espanhol). Acesso em: 15 ago. 2014.

STOLEROFF, A., PATRÍCIO, M. T. A prática científica. In: JESUÍNO, J. C. (Coord.) et al. A comunidade científica portuguesa nos finais do século XX. 2.ed. Oeiras, Portugal: Celta, 1995. 185 p., p.13-32.

TORRADO, Enrique Muriel. Los derechos de autor y la enseñanza em la universidad: el papel de la biblioteca universitária. Tesis Doctoral Universidad de Granada, Faculdad de Comunicación y Documentación. Departamento de Información y Documentación. Granada, 2012. 500p.

UNIVERSIDADE Tecnológica Federal do Paraná. Pato Branco, [201?]. Direitos Conexos. Disponível em: <http://www.utfpr.edu.br/patobranco/estruturauniversitaria/diretorias/direc/nit/pi/direito-autoral/direitos-conexos>. Acesso em: 07 maio 2016. 
WEITZEL, Simone da Rocha. Iniciativa de arquivos abertos como nova forma de comunicação científica. Grupo de discussão: Como democratizar a comunicação nas novas mídias (internet - inclusão digital). In: SEMINÁRIO INTERNACIONAL LATINO-AMERICANO DE PESQUISA EM COMUNICAÇÃO, 3. São Paulo, Anais... São Paulo, 2005. [Asociación Latinoamericana de Investigaciones de la Comunicación-ALAIC; Escola de Comunicações e Artes da Universidade de São Paulo]. Disponível em: <http://www.academia.edu/3333810/Iniciativa_de_arquivos_abertos_como_ nova_forma_de_comunica\%C3\%A7\%C3\%A3o_cient\%C3\%ADfica>. Acesso em: 23 mar. 2014.

WILLINSKY, J. The access principle: the case for open access to research and scholarship. London: The Mit Press, 2006. 